\title{
Design of Indonesian Paradila Woven Tied Batik
}

\author{
Yekti Herlina \\ Surabaya Wilwatikta Art Institution \\ Surabaya, Indonesia \\ linayekti@yahoo.co.id
}

\begin{abstract}
Abstact-The industry of Indonesian Paradila is the weaving industry producing sarong woven cloth, and the newest product, that is batik tied woven cloth. Paradila batik tied woven cloth has been produced for 2 years. The fabric material used is tied woven cloth combined with batik in cat fish and milk fish motifs as the typical characteristics with any kinds of fillings among others are pyur, jasmine, and uker. The developing motifs in common are influenced by geographical environment, potential of natural sources which exist in the environment. This research has a purpose to find out the batik design used, the motif arrangement, and the process of the batik tied woven creation. This research is expected to give advantages to companies and weavers to find out names of the designs in woven tied batik cloth produced. The method used in this research is descriptive qualitative and experiments. The report was explained in descriptive way. The result of this research gives contribution, inspiration, and also important innovation in the effort to build creative way of thinking, critical, especially to those related to the design and the process of creating woven tied cloth as the material of batik so that it becomes appealing and growing the creative business in the field of batik art.
\end{abstract}

Keywords-Batik. Design, Woven Tied

\section{INTRODUCTION}

The purpose achieved in this research is to find out the design and the batik motifs used, also the creation process of the woven tied batik. The motif designs produced will be the typical characteristics of woven tied batik. Cat fish and Milk fish become the typical characteristics of batik completed with pyur, jasmine and uker fillings. The craft of woven tied cloth, songket, and batik are a few of the woven cloth industrial centers in Indonesia. The creation in which has the ability to make any kinds of motifs of woven cloth from generation to generation and becomes one of creativities supporting the increase of the society's economy. Batik in Indonesia is centered and develops fast in Java island. In its development, batik develops in any design variations, and different motifs and features. The woven batik cloth uses catfish and milk fish as the characteristics with fillings of pyur, jasmine, and uker applied on Paradila woven cloth. There are the designs from the creation of the owner and there are the ones from consumer's order with the design based on the customer's tastes. This business has been run in a long time and there haven't been any problems and complaints from customers regarding to the results of the woven products produced by Paradila. The process in making the woven tied cloth is categorized as woven woof cloth because the process of making the motifs on this kinds of woven cloth is carried out at the time of weaving and based on the woof thread. The motifs of tied woven cloth are mostly mixed in one piece of woven cloth, for instance, geometric motifs are mixed with flowery or plant motifs so that there won't be a tendency towards the finished result of the woven cloth. Although there are geometric motifs only, every motif created has different name and shape. With the more developed tied woven cloth and Paradila songket, it has been almost 2 years that the batik design of catfish and milk fish have been considered as the typical characteristics added on tied woven cloth so that it increases a high sale value. From the example above, the problem can be formulated, that is how the motif design and the concept of the woven tied batik creation which becomes the typical characteristic of Indonesian paradila batik. [1] explained that batik in Indonesia at first was known as a Javanese handy craft product. If it is analyzed from the origin of the word "batik" (etymology), the word batik is originated from Indonesia (java) word meaning to make dots using hot candle on cloth [2].

Batik has developed so fast, after batik was claimed by UNESCO on October 2009 as "The humanity heritage for non hylic and oral culture". In any regions in Indonesia people competed to develop batik designs/ batik motifs. Since 2012 with any variations, milk fish and catfish batik motifs have often been contested in Lamongan. It was proven the participants of batik contests in Lamongan area increased from 139 participants in 2014 to 139 participants in batik design competition in 2015 [3].

\section{METHODS}

This research uses qualitative descriptive and experiment. The report was explained in descriptive way. The research data were obtained by interviewing Mr. Miftahul Khoiry, some Lamongan batik craftmen, and the trade and industry department of Lamongan regency [4]. The data were also obtained through literature and internet sources. Experiment method was carried out to create the batik motif designs which then were discussed with Mr. Miftahul Khoiry and some batik craftsmen. From the research result, there were some data obtained that is design of Paradila woven tied batik cloth which has typical lamongan characteristics that is milk fish and catfish motifs with jasmine, pyur, and uker motifs added. Batik has a lot of philosophy, in its development today, people only consider batik from business 
point of view then it past times batik was an expression of craftmen's feeling expression [5].

The development of woven tied cloth and songket are not two separated things. Because in a woven tied cloth may also be added songket in it. The problem is that in songket process there is also weaving stage. Besides the technique and the results in original tied woven cloth, in some other models there are decorations in songket technique added, sometimes it was also attached on doby cloth, that is a kind of cotton with embossed motifs [6].


Fig 1. Paradila Plain Tied Woven

For design problem, Paradila which ever got Muri certificate by making the longest woven tied cloth, that is 60 meters, routinely upgrades the following era development so that buyers will not easily feel bored. The design like gunungan model is made based on old designs [7]. With the more developed of Paradila woven tied cloth and songket, then it has been almost 2 years that batik design has been added on woven tied cloth so that it adds a high sale value.

\section{RESULT AND DISCUSSION.}

Today it has been carried out a creation business of Paradila woven tied batik design. The purpose od Paradila batik woven tied cloth is the effort to develop and conserve Indonesia. Several motif shapes have been created a lot by Paradila woven tied cloth industry, even there are many motifs which haven't been created anymore, because the owner of this industry does not rely on the same motifs. There are several motifs of Paradila woven tied cloth among others are animal motifs, plant motifs, natural event motifs, gunungan motif, mixture and combination motif, geometric motif which is the first motif in the creation of the woven tied cloth from the past time till today [8]. The design of woven tied cloth with gunungan motif, songket and catfish and milk fish batik with the fillings of jasmine, pyur and ukel becomes the typical characteristic of Indonesian batik.

\section{A. The Meaning of Milk Fish and Catfish}

The Paradila woven tied batik design has typical characteristic of catfish symbolizing a tenacious and tough life style, patient but tenacious, if bothered they are brave to attack with their shafts as their powerful weapons. Milk fish symbolizes new potency of commodity to Lamongan regency with full of expectation in the future [9]. The milk fish and catfish woven tied batik Creating batik motifs need specific knowledge and skills.



Fig 2. Weaving batik of Catfish and Milkfish fish

The motifs which will be created can really express the quality of other motifs compared with the available batik motifs. In creating batik motifs, we can learn how to make kinds of fillings of plant shape stylation, animal shape stylation, and human shape stylation and filling certain space shape [10].

\section{B. Kinds of Fillings}

To be able to create nice batik motifs, first we should know any kinds of fillings. There are many kinds of fillings [11]. One of them is line shape (Klowong) which may be made in any kinds of variations so that the shapes achieved can give various impressions, besides they can be made freely [12].

\section{Kinds of Cecek Shape Fillings:}

- Cecek: pyur cecek, uwer cecek, ukel cecek, etc.

- Filled cecek: Cecek arranged in half circle, Filled cecek based on the shape of its circle.

- Flowery cecek: half small and big circles, half small and big circles on hal big circle given limitations (tembokan). The filling used is jasmine flower symbolizing holiness, pyur and ukel [13].



Fig 3. Kinds of fillings of Lamongan Paradila woven tied batik

\section{CONCLUSION}

Batik in Indonesia experiences a very rapid development, after batik was claimed on 2 October 2009 as "The Heritage of Humanity for Oral and Non Hylic Culture". In any regions in Indonesia craftsmen compete to develop batik motifs and designs. Every creation made by the owner of the woven tied cloth has motifs with various designs. The 
motifs created by Mr. Mifathul Khoiry adapted and adopted from natural shapes or the ones called back to nature and it is not rare that natural events happen in Indonesia can be inspiration to the creation of new motifs.

The development of the geometric motifs on woven tied cloth, songket, and Paradila batik tend to be simple geometric shapes, like rhombus (diamond), square, stripes, any shapes (triangle, Pentagonal, hexagonal) and gunungan motif develops to be woven tied cloth, songket, and Paradila batik.

To respond this case, any kinds of reports to increase batik business in Lamongan by building creative, critical ways of thinking especially to those related to economic plus point towards the industrial products of the woven tied cloth and Indonesia Paradila batik.

To respond this case, any kinds of efforts to increase batik business have been carried out by building creative and critical ways of thinking especially to those plus economic value to the industrial products of Indonesian Paradila woven tied cloth and batik.

In fact, there are still many potentials to develop new creation of batik designs on milk fish and catfish applied on Paradila woven tied cloth so that it adds a high sale value. The design and motifs of catfish and milk fish with the fillings of jasmine, pyur, and ukel become the typical characteristics of Indonesian Paradila batik.

\section{REFERENCES}

[1] Karsam. 2005. Dissertation. The Art of Writing in Kota Bharu, Kelantan, Malaysia and In Tuban Regency, East Java Indonesia: A Comparative Study. Kuala Lumpur: Malay Studies Academy, University Malaya.

[2] Sastrodiwirjo, Kadarisman. 2012. The Haritage Of Indonesia Pamekasan Membatik. Ed. Ke- 2 PT. Jepe Press Media Utama

[3] Public Relations Bureau of East Java Regional Government. 2010. Potential of People's Craft in East Java.

[4] Chandra Irawan, Soekamto. 2011. Pattern Batik. Jakarta: Publisher PT Akadoma

[5] Dofa, Anesia Aryunda, 1996. Batik Indonesia. Jakarta: The publisher of PT Golden Terayon Press.

[6] Herlina, Yekti, "Creativity and Composition in the Art of Photography" dalan Jurnal Terob, Volume IV Number 1 April 2012. P.91

[7] Hackett, John. 1986. Industrial Design. Jakarta: CV Rajawali Publisher.

[8] [7] Nazir, Moh.2003. Research methods. Jakarta: Ghalia Indonesia.

[9] Sachari, Agus. 2007. Visual Culture Indonesia. Faculty of Arts and Design, Erlangga, Bandung.

[10] Sachari, Agus, 2007, Design of Style and Reality, Penebar Swadaya, Jakarta

[11] Sajiman, 2010, Production, Yogyakarta, Pennarbit Jata Sucrera.

[12] Susanto, Mikke..Diksirupa.Yogyakarta: Penerbit Dikti Art Lab

[13] Toekio M, Soegeng. 1979. Knowing Indonesian Ornamental Variety. Bandung: Angkasa Publishers. 